\title{
THE PlACE OF THE EMPLOYMENT COURT IN THE NEW ZEALAND JUDICIAL HIERARCHY
}

\section{Paul Roth*}

This article considers the status of the Employment Court and its position in the overall court structure in New Zealand. It examines the issue from both an historical and comparative New Zealand legal perspective.

Professor Gordon Anderson has written much on the Employment Court and its predecessors. He championed its independent existence as a specialist court ${ }^{1}$ when it was under sustained attack in the 1990s by the Business Roundtable and New Zealand Employers' Federation (both now absorbed by or transformed into different organisations), ${ }^{2}$ and by some in the then National government. ${ }^{3}$ The

* Professor, Faculty of Law, University of Otago.

1 See Gordon Anderson A Specialist Labour Law Jurisdiction? An Assessment of the Business Roundtable's Attack on the Employment Court (Gamma Occasional Paper 5, 1993); Gordon Anderson "Specialist Employment Law and Specialist Institutions" (paper presented to the New Zealand Institute of Industrial Relations Research Seminar on the Future of the Employment Court and the Employment Tribunal, 23 April 1993); Gordon Anderson "The Judiciary, the Court and Appeals" [1993] ELB 90; and Gordon Anderson "Politics, the Judiciary and the Court - Again" [1995] ELB 2.

2 See New Zealand Business Roundtable and New Zealand Employers' Federation A Study of the LabourEmployment Court (December 1992); Colin Howard Interpretation of the Employment Contracts Act 1991 (New Zealand Business Roundtable and New Zealand Employers Federation, June 1996); Bernard Robertson The Status and Jurisdiction of the New Zealand Employment Court (New Zealand Business Roundtable, August 1996); and Charles W Baird "The Employment Contracts Act and Unjustifiable Dismissal: The Economics of an Unjust Employment Tax" (New Zealand Business Roundtable and New Zealand Employers Federation, August 1996). The Business Roundtable merged with the New Zealand Institute in 2012 to form the New Zealand Initiative, a business-oriented think tank. The New Zealand Employers' Federation merged with the New Zealand Manufacturers Federation in 2001 to form BusinessNZ, which is now an amalgamation of the Employers and Manufacturers' Association (EMA), Business Central, the Canterbury Employers' Chamber of Commerce and the Otago Southland Employers' Association.

3 See Max Bradford, Minister of Labour (speech at the Employment Relations Conference, Auckland, 9 July 1997); and Bill Birch, Minister of Finance (speech to the Wellington District Law Society, 7 June 1997). 
Court's fight against abolition or absorption was staved off, ${ }^{4}$ largely because its critics moved on to target the Court of Appeal's employment law decisions. The sharp decrease in work experienced by the Employment Court under the Employment Relations Act 2000 (ER Act 2000), however, now offers a tempting target for the rationalisation or reorganisation of judicial resources.

It would be unfortunate if the very success of the dispute resolution system put in place under the ER Act 2000 were to lead to the Court's demise. One of the objects of the ER Act 2000 was "to reduc[e] the need for judicial intervention", 5 and the Act has been successful in achieving this. The Court is the third and final specialist institution in the employment relations dispute resolution system (the first two being the mediation services and the Employment Relations Authority). The majority of the Court's cases tend to be challenges to Employment Relations Authority determinations, the more complex legal issues and issues of wider institutional importance. In any event, the Court's workload, and its status, are two quite different matters.

In its 2004 report on the New Zealand court structure, the Law Commission recommended that the Employment Court should continue to exist as a specialist court, but with a diminution in status, so that it would not sit "near the level of the High Court" as at present, ${ }^{6}$ but be positioned beneath the High Court in the judicial hierarchy. ${ }^{7}$ The Law Commission proposed that the Employment Court should be part of a proposed first instance "Primary Court" structure that includes the District Court and other inferior courts. General appeals from Employment Court decisions on fact and law would be determined in the High Court (unlike the present position), and from there by leave on matters of law only in the Court of Appeal and Supreme Court. Moreover, applications for review of Employment Court decisions would be heard in the High Court rather than the Court of Appeal. While the Law Commission acknowledged that the Employment Court would lose status by becoming a Primary Court, it considered that "clarity and accessibility for court users weigh more heavily against this concern". ${ }^{8}$ The government rejected these proposals.

Given the Law Commission's conclusions, it seems important to revisit the Employment Court's history and continuing relevance as a stand-alone specialist court whose status is roughly on par with, if somewhat below, that of the High Court. Anderson's analyses of the position and role of the

4 Though there continues to be calls for the Court's abolition from time to time: "Business New Zealand Update" (23 May 2003) Scoop Independent News < www.scoop.co.nz>.

5 Employment Relations Act 2000 [ER Act 2000], s 3(a)(vi).

6 Law Commission Delivering Justice for All: A Vision for New Zealand Courts and Tribunals (NZLC R85, 2004) at [285].

7 At [226]-[227] (Recommendations 114-117).

8 At [288]. 
Employment Court continue to be as important today as they were in the 1990s for an appreciation of this subject.

\section{HISTORICAL OVERVIEW OF THE SPECIALIST COURT}

The Employment Court, established in 1991, is a specialist court whose lineage can be traced in an unbroken line back to its establishment by the Industrial Conciliation and Arbitration Act 1894 (IC\&A Act 1894) as the Court of Arbitration (1894-1973), ${ }^{9}$ followed by the Industrial Court (19731977), the Arbitration Court (1977-1987) and the Labour Court (1987-1991). Over its lengthy history, the Court has undergone much development, particularly in the past 30 years. The Court of Arbitration began as a wage-fixing body, but from the 1970s onwards the powers of its successor courts were limited to determination of an ever-increasing range of legal disputes.

\section{A The Judiciary: From the Court of Arbitration to the Employment Court}

The original Court of Arbitration consisted of a Supreme Court (High Court) judge ${ }^{10}$ and two lay members, one representing unions, the other employers' associations. The Supreme Court judge, who served as President of the Court of Arbitration, was appointed by the then Governor, and any temporary replacement had to be a Supreme Court judge as well. ${ }^{11}$ The qualification for appointment thus was, initially, to be a Supreme Court judge, but subsequently it was sufficient if the requirements for appointment as such a judge were satisfied. The protection of tenure and remuneration was, and continues to be, the same as for a High Court judge.

Initially, a judge of the Court of Arbitration would be appointed for a three-year term, and be eligible for reappointment. ${ }^{12}$ The first six judges of the Court of Arbitration, who sat between 1896 and 1906, served for short terms of between one and three years each. ${ }^{13}$ The President of the Court of Arbitration performed his duties in addition to his ordinary duties in the Supreme Court, but by 1900 the workload had increased to such an extent that an extra Supreme Court judge was appointed,

9 Section 47.

10 Equivalent of a High Court judge today.

11 Industrial Conciliation and Arbitration Act 1894 [IC\&A Act 1894], s 48(1).

12 IC\&A Act 1894, s 49(1)

13 JS Williams (1896-1897); JE Denniston (1898); WB Edwards (1898-1900); JC Martin (1900-1901); T Cooper (1901-1903); and FR Chapman (1903-1906). For a list of all of the judges of the Employment Court and its predecessors, and their terms of office, see: Employment Court of New Zealand "About the Employment Court: The Judges" (21 November 2018) <www.employmentcourt.govt.nz>. 
on the understanding that most of his work would be in the Court of Arbitration. ${ }^{14}$ It was the practice until 1921 for the most junior puisne judge of the Supreme Court to be appointed to the Court of Arbitration. ${ }^{15}$ The last statute that provided that a judge of the Court of Arbitration must also be a judge of the Supreme Court was the Industrial Conciliation and Arbitration Amendment Act 1905. ${ }^{16}$ The term of office continued to be three years unless a successor was appointed, or the term was renewed. ${ }^{17}$

The following year, the judicial qualification was altered by the Industrial Conciliation and Arbitration Amendment Act 1906, so that the appointee no longer was required to be an existing judge of the Supreme Court, but merely had to be "some fit person" who "is eligible to be a Judge of the Supreme Court". ${ }^{18}$ The appointee would have the same rights as to tenure of office, remuneration, rights and privileges as a Supreme Court judge, ${ }^{19}$ and could be appointed from time to time as a temporary judge of the Supreme Court when judicial assistance was needed. ${ }^{20}$ Secretary of Labour Edward Tregear objected to this measure "on the grounds that the Court owed its prestige and hence its authority to the presence of a Supreme Court judge on the bench". ${ }^{21}$

In the Industrial Conciliation and Arbitration Act 1925, the position was altered again, in that there was no longer a reference to possible appointment of a Court of Arbitration judge as a temporary judge of the Supreme Court. If, however, a Court of Arbitration judge was prevented from sitting because of illness or unavoidable absence, then the Governor-General could appoint a Supreme Court judge to act in his place during the absence. ${ }^{22}$

14 Noel S Woods Industrial Conciliation and Arbitration in New Zealand (Government Printer, Wellington, 1963) at 65; and James Holt Compulsory Arbitration in New Zealand: The First Forty Years (Auckland University Press, Auckland, 1986) at 62.

15 DL Mathieson Industrial Law in New Zealand (Sweet \& Maxwell, Wellington, 1970) vol 1 at 291.

16 Section 65(2).

17 Section 67(1).

18 Section 2(1)-(2), essentially re-enacted as s 65(1) of the Industrial Conciliation and Arbitration Amendment Act 1908 [IC\&A Amendment Act 1908], and carried over into the Industrial Conciliation and Arbitration Act 1925 [IC\&A Act 1925], s 64(1); the Industrial Conciliation and Arbitration Act 1954 [IC\&A Act 1954], s 18(1); the Industrial Relations Act 1973 [IR Act 1973], s 37(1); the Industrial Relations Amendment Act 1977 [IR Amendment Act 1977], s 37(1); the Labour Relations Act 1987 [LR Act 1987], s 288(2); the Employment Contracts Act 1991 [EC Act 1991], s 113(2); and the ER Act 2000, s 200(2)(a).

19 Section 2(3), re-enacted as s 65(2) of the IC\&A Amendment Act 1908.

20 Section 2(4), re-enacted as s 65(3) of the IC\&A Amendment Act 1908.

21 Holt, above n 14, at 62-63.

22 IC\&A Act 1925, s 64(3). 
The Industrial Conciliation and Arbitration Act 1954 (IC\&A Act 1954) omitted the reference to Court of Arbitration judges receiving the same remuneration as Supreme Court judges, and instead provided for a salary of $£ 3,000$, with travelling allowances to be fixed by the Governor-General from time to time. ${ }^{23}$ This provision was amended by the Industrial Conciliation and Arbitration Amendment Act (No 2) 1970, which provided that the salary of judges of the Court of Arbitration would be fixed by the Governor-General from time to time, as would travelling allowances. ${ }^{24}$ This remained the position until the Labour Relations Act 1987 (LR Act 1987), when remuneration was fixed by the Higher Salaries Commission, ${ }^{25}$ and then subsequently by the Remuneration Authority. ${ }^{26}$

With time, the judges held tenure for longer periods, indicating that the position was becoming a long-term career option. In contrast to the high turnover of judges in the first decade of the conciliation and arbitration system, between 1907 and 1920, two judges served for about six years each. ${ }^{27}$ Sitting on the Court of Arbitration became even more of a long-term proposition thereafter, as illustrated by F V Frazer, who served from 1921 to 1935, A Tyndall (1940 to 1965) and A P Blair (1964 to 1974), ${ }^{28}$ although a number of judges served for shorter periods as well. The past 30 years have seen a large number of judges sit for a decade or longer, ${ }^{29}$ with the current record held by former Chief Judge G L Colgan, who was on the bench for 28 years. ${ }^{30}$

\section{B Persistent Characteristics of the Specialist Court, and Inevitable Change}

One constant is that the specialist court has never generally been a first instance institution. It has always been a second-tier institution, for most of its history sitting above lay bodies (from the Conciliation Boards in the IC\&A Act 1894, to disputes and grievance committees, and the Arbitration

23 IC\&A Act 1954, s 19(1).

24 Section 2. See subsequently the IR Act 1973, s 38(1); and the IR Amendment Act 1977, s 39(1).

25 Section 290(1), carried over into the EC Act 1991, s 115(1).

26 ER Act 2000, s 206(1), as amended in 2003 by the Remuneration Authority (Members of Parliament) Amendment Act 2002, s 4(1).

27 W A Sim (1907-1913); and T W Stringer (1914-1920).

28 A P Blair sat in both the Court of Arbitration (1964-1973) and in the successor institution, the Industrial Court (1974).

29 NP Williamson (Arbitration Court 1978-1987, Labour Court 1987-1988); JRP Horn (Arbitration Court 1978-1987, Labour Court 1987-1989, 1991); DS Castle (Arbitration Court 1980-1987, Labour Court 19871991, Employment Court 1991-1995); DD Finnegan (Arbitration Court 1985-1987, Labour Court 19871991, Employment Court 1991-1998); BA Palmer (Labour Court 1987-1991, Employment Court 19912003); BS Travis (Labour Court 1989-1991, Employment Court 1991-2013); TG Goddard (Labour Court 1989-1991, Employment Court 1991-2005); AA Couch (Employment Court 2005-2014); and CM Shaw (Employment Court 1999-2009).

30 Labour Court (1989-1991) and Employment Court (1991-2017). 
Commission $^{31}$ under the LR Act 1987). From 1991 onwards, it has sat above legal bodies: the Employment Tribunal (under the Employment Contracts Act 1991 (EC Act 1991)) and the Employment Relations Authority (under the ER Act 2000). ${ }^{32}$ From its inception, the specialist court has heard matters that could be described as being in the nature of an appeal, and for much of its history it issued decisions that were, in effect, final and dispositive. These characteristics distinguish the specialist court from the District Court, which (with a few exceptions) sits as a first-tier institution. The Employment Court and its forebears have always been the senior court within their specialist jurisdiction.

Another constant is that the status of the Employment Court in the judicial hierarchy has always been higher than that of the District Court (formerly the Magistrates' Court), and somewhat lower than the High Court. Nevertheless, where a decision on the same point of law arose in turn in the Supreme Court and the Arbitration Court, the Supreme Court normally put weight on the relevant decision of the Arbitration Court, even though it was not binding on it, ${ }^{33}$ and the Arbitration Court was not bound to defer to the Supreme Court. As Mathieson commented, "having no appellate jurisdiction in respect of Court of Arbitration decisions, [the Supreme Court] is not its superior in the judicial hierarchy". ${ }^{34}$ Mathieson went on to observe that "in one notable instance", the Arbitration Court "refused to follow a considered decision of Myers CJ". ${ }^{35}$

In 1977 the Minister of Labour observed that the position of the Arbitration Court in the overall court structure was one "having slightly less jurisdiction than, but something of the same status as, the Supreme Court [High Court]". ${ }^{36}$ That characterisation is more true now than it was at the time with the expansion of the specialist court's jurisdiction, to a large extent carved out of the High Court's jurisdiction.

In 2016, the appointment of acting Employment Court judges was altered by specifying that an acting judge could be either a former Employment Court judge or a "current or former District Court Judge". ${ }^{37}$ This reflects the reality that since the 1970s, six Arbitration Court, Labour Court and

31 Under s 277 of the LR Act 1987, the Commission could state a case for the opinion of the Court, whose decision would be final and binding.

32 The Law Commission, however, has considered that the role of the Authority "does not transform the role of the Employment Court into an appellate one. It remains a court which makes primary adjudications": Law Commission, above n 6, at [286].

33 Thomas Borthwick \& Sons (Australasia) Ltd v Haeata [1965] NZLR 957 (SC), as cited in Mathieson, above n 15 , at 298.

34 At 298.

35 At 298, citing Lyttelton Harbour Board v McGregor [1944] NZLR 258 (SC).

36 (17 November 1977) 415 NZPD 4582.

37 ER Act 2000, s 207(4), as replaced by the Employment Relations Amendment Act (No 2) 2016. 
Employment Court judges had been Magistrates' Court ${ }^{38}$ or District Court judges, ${ }^{39}$ or held concurrent warrants. This position undoubtedly stems from two factors that have developed in recent years.

One is that the appointment of a High Court judge to the Employment Court would now amount to a "demotion". ${ }^{40}$ The centrality of state-sponsored wage-fixing and the maintenance of a highly structured system of industrial relations no longer exists in New Zealand's current market economy.

The other factor is the enhanced standing of the District Court, which replaced the Magistrates' Court in 1980 and assumed an expanded jurisdiction on the recommendations of the 1978 Royal Commission on the Courts. ${ }^{41}$ The Magistrates' Court had dealt with minor criminal and civil matters from 1893 until 1980, when the stipendiary magistrates became District Court judges. The extended jurisdiction of the District Court that covers the middle band of criminal offences was carved out of the High Court's jurisdiction, so that the District Court's criminal jurisdiction allows it to deal with most criminal matters, including jury trials. The only offences that it cannot deal with are category 4 offences, ${ }^{42}$ such as murder, manslaughter and crimes against the state. Its sentencing powers are also limited, in that it cannot impose sentences of life imprisonment or preventive detention. Its civil jurisdiction is limited to matters involving less than $\$ 350,000$. While awards of damages in the specialist employment law jurisdiction are not statutorily limited, in practice they rarely exceed that amount, and more often they are far less. The District Court also operates as an appellate or supervisory court for some lower tribunals and authorities, such as the Disputes Tribunal, the Tenancy Tribunal and Accident Compensation Corporation (ACC) review hearings.

\section{C "Judicialisation" of the Court}

As Anderson has noted, "the arbitration system was never fully autonomous". ${ }^{43}$ It did not cover actions dealing with employment contracts or the economic or "industrial" torts. Moreover, the courts

38 JRP Horn, appointed to the Arbitration Court in 1978 and appointed Chief Judge of the Labour Court in 1987; and B Palmer, appointed to the Labour Court in 1988 and later appointed to the Employment Court.

39 C Shaw had been a District Court judge from 1992 to 1999 before her appointment to the Employment Court. M Perkins was appointed a District Court judge in 1999 and was appointed to the Employment Court in 2009; he had been appointed a temporary judge for one year in 2006-2007. The current Chief Judge, C Inglis, had been appointed a District Court judge in 2010 before being appointed to the Employment Court in 2011. T Couch was appointed to the District Court and Employment Court in 2005.

40 The salary of a High Court judge, however, would not be reduced by reason of appointment to the Employment Court: Constitution Act 1986, s 24.

41 See Law Commission Seeking Solutions: Options for change to the New Zealand Court System (NZLC PP52, 2002) at $155-157$.

42 See sch 1 of the Criminal Procedure Act 2011.

43 Gordon Anderson "The Common Law and the Reconstruction of Employment Relationships in New Zealand" (2016) 32 IJCLIR 93 at 98. 
of general jurisdiction decided whether an individual was a "worker" or not for the purposes of determining the existence of union coverage and eligibility for workers' compensation. Anderson reminds us that: ${ }^{44}$

... until the 1970s, the Court of Arbitration's primary function was economic and the more judicial side of the system's work - the enforcement of awards and penalty actions - was, until 1973, largely the province of the Magistrates' Court ...

as well as the Supreme Court. ${ }^{45}$ The establishment of the relabeled Industrial Court in 1973 marked the genesis of the specialist court's judicial character "as its traditional economic role diminished". ${ }^{46}$ In particular, the Court's new jurisdiction over personal grievances in 1973 required it to develop the relevant legal principles and case law. ${ }^{47}$

The jurisdiction of the specialist court grew considerably with the enactment of the LR Act 1987, and this trend continued with the establishment of the Employment Court under the EC Act 1991. Under these enactments, the specialist court progressively became more like a conventional court. Woods described the unique contribution of the Court of Arbitration's judges to the success of the conciliation and arbitration enterprise as follows: ${ }^{48}$

The system owes much of its strength to the outstanding qualities of successive Judges in maintaining the dignity of the office with a minimum of formality, in demonstrating a wide and practical grasp of economic and technical problems and human relationships, and in winning the confidence of all parties.

While this description might still hold true on the ground today, these are not qualities that the appellate courts hold in particularly high esteem, despite legislative direction that they have regard to the special jurisdiction and expertise of the specialist court. ${ }^{49}$

The Labour Court established under the LR Act 1987 became less tripartite in its functions. There was a reduced role for lay members, which the EC Act 1991 dispensed with entirely. The Labour Court heard matters under the LR Act 1987 with a judge alone or a Full Court of three judges. For

44 Gordon Anderson Reconstructing New Zealand's Labour Law: Consensus or Divergence? (Victoria University Press, Wellington, 2011) at 103.

45 See for example IC\&A Act 1894, pt II and ss 23 and 75-76.

46 Anderson, above, $\mathrm{n} 44$, at 104.

47 IR Act 1973, ss 47(2)(g) and 117. This new jurisdiction was originally added to the IC\&A Act 1954, as amended in 1970 by s 179(2), which referred to "wrongful dismissal", a common law concept that was replaced by the statutory concept of "unjustifiable dismissal" in 1973.

48 Woods, above, n 14, at 10.

49 IR Act 1973 (as amended in 1977), s 62A(4); LR Act 1987, s 314; EC Act 1991, s 137; and ER Act 2000, s 216(1). 
demarcation disputes, ${ }^{50}$ personal grievances, ${ }^{51}$ and parental leave complaints, ${ }^{52}$ a judge and two lay panel members decided the issue as under previous incarnations of the specialist court. The 1987 changes marked the Labour Court "as having a more exclusively legal function than the former Arbitration Court". ${ }^{53}$

The existence of a lay element had signalled that "the Court was intended to employ not only legal rules, but also the industrial expertise of its nominated members and those appearing before it"; ${ }^{44}$ lay representatives being the norm. From 1894 until 1987, representation by barristers or solicitors could only occur with the consent of all of the parties, ${ }^{55}$ and Mathieson remarked that "[i]n practice consent is never forthcoming". ${ }^{56}$ Moreover, the legislation until 1973 did not allow costs to be awarded in respect of barristers or solicitors, which had a further dampening effect on the use of legal counsel. ${ }^{57}$ In the LR Act 1987, lay representation was preserved only by prohibiting a barrister or solicitor holding a practising certificate from acting as a negotiator on a conciliation council or representing a party before the Conciliation Commission unless all of the parties agreed. ${ }^{58}$

The LR Act 1987 established a separate Arbitration Commission to deal with disputes of interest, ${ }^{59}$ which under earlier legislation had been determined by the specialist court. This resurrected the short-lived Industrial Commission established under the Industrial Relations Act 1973 [IR Act 1973], ${ }^{60}$ but which was in turn replaced by the Arbitration Court under the Industrial Relations Amendment Act 1977 [IR Amendment Act 1977]. ${ }^{61}$

50 Section 108(6).

51 Section 217(2).

52 Parental Leave and Employment Protection Act 1987, s 61(4).

53 Martin Vranken "Specialisation and Labour Courts: A Comparative Analysis" (1988) 9 Comparative Lab L J 497 at 517.

54 At 515 .

55 IC\&A Act 1894, s 53; IC\&A Amendment Act 1905, s 79; IC\&A Amendment Act 1908, s 80; IC\&A Act 1925, s 79; IC\&A Act 1954, s 139; IR Act 1973, s 54; and IR Amendment Act 1977, s 54(4).

56 Mathieson, above n 15, at 294.

57 IC\&A Act 1894, s 69(1); IC\&A Amendment Act 1905, s 87; IC\&A Amendment Act 1908, s 87; IC\&A Act 1925, s 86; and IC\&A Act 1954, s 50.

58 Sections 141(3) and 274(1)(c). No costs were allowed for the appearance of barristers or solicitors before the Conciliation Commission: s 272(6).

59 Section 261.

60 Section 17.

61 Section 48(1). Section 2 of the Amendment Act abolished the Industrial Commission. 
Under the LR Act 1987, the Labour Court took over a number of jurisdictions carved out from the courts of general jurisdiction, in particular:

- $\quad$ sole jurisdiction over injunctions 62 and the "economic" torts relating to strikes and lockouts, ${ }^{63}$ namely conspiracy, intimidation, inducement of breach of contract and interference by unlawful means with trade, business, or employment; and

- judicial review of statutory powers of decision in the employment law sphere, ${ }^{64}$ with an appeal right to the Court of Appeal. The Court of Appeal, not the High Court, in turn had the exclusive power to review the Labour Court. ${ }^{65}$

The Labour Court also took jurisdiction over an increased number of workers. With the 1987 LR Act came the abolition of a number of existing tribunals (for agricultural workers, the waterfront industry and aircrew), who then came under the Court's jurisdiction. The State Sector Act 1988 brought the Public Service and the education service under the Labour Court's jurisdiction. ${ }^{66}$ Under the EC Act 1991, exclusive jurisdiction over individual employment contract matters was carved out for the Employment Court, further adding to the specialist court's legal coverage of workers. Prior to 1991, the specialist court only had jurisdiction (with minor exceptions) over unionised workers covered by the statutory award system. Other workers were only able to pursue common law actions in the courts of general jurisdiction.

Under the EC Act 1991, the specialist court acquired an appellate and supervisory jurisdiction over the new Employment Tribunal established below it. The Employment Court had final jurisdiction over the construction of both individual and collective employment contracts (the latter carried over and adapted from the LR Act 1987), and it finally determined all employment matters except questions of law, which could be appealed to the Court of Appeal.

The "judicialisation" of the specialist court that had begun in the 1970s thus reached its current apogee by the 1990 s. ${ }^{67}$ This has produced increased formality, technical legalism and complexity of the law; ${ }^{68}$ increased representation of parties by lawyers and professional advocates; and an increase

62 Section 243.

63 Section 242.

64 Section 280. See also ER Act 2000, s 194.

65 Section 308. See also ER Act 2000, s 213.

66 State Sector Act 1988, ss 67 and 73 respectively.

67 Rose Ryan and Pat Walsh "Common Law v Labour Law: The New Zealand Debate" (1993) 6 AJLL 230.

68 Susan Robson "Policy, Operations and Outcomes in the New Zealand Employment Jurisdiction 1990-2008" (PhD Dissertation, University of Otago, 2017) at 49. 
in the length of judgments, whose production must undoubtedly slow down their delivery to anxious litigants.

The nature and work of the specialist court has changed markedly from when it was primarily a wage-setting body. While the jurisdiction of the specialist court has greatly expanded, its new panoply of powers invites invidious comparison with the High Court. The specialist court now appears to come somewhat short when the two are compared on more equal terms. At the same time, however, developments over the past 30 years or so have shown that the specialist court has become more like a senior court than at any other time in its history.

\section{THE STATUS OF THE SPECIALIST COURT IN THE NEW ZEALAND JUDICIAL HIERARCHY}

There are a number of features, additional to some touched upon above, that indicate that the status of the Employment Court in the judicial hierarchy is roughly analogous to that of the High Court, if somewhat below it due to its specialist jurisdiction.

\section{A Appointment and Removal}

Senior Court judges (of the High Court, Court of Appeal and Supreme Court) have the highest judicial status in the New Zealand legal system. They are appointed by the Governor-General "in the name and on behalf of Her Majesty" on the recommendation of the Prime Minister. ${ }^{69}$ Employment Court judges, like District Court judges, are appointed by the Governor-General on the advice of the Attorney-General. ${ }^{70}$

The grounds for removal, however, are the same for Employment Court and senior court judges: misbehaviour and incapacity. ${ }^{71}$ The grounds for removal of District Court judges and Associate Judges of the High Court, misbehaviour and inability, ${ }^{72}$ are similar, but "inability" bears a wider meaning in that it could include incompetence. ${ }^{73}$

The mode of removal for Employment Court and High Court judges is also the same: it is by the Sovereign or the Governor-General acting upon an address of the House of Representatives. ${ }^{74}$ In

69 Senior Courts Act 2016, s 100.

70 ER Act 2000, s 200(1); and District Court Act 2016, s 11(1).

71 ER Act 2000, s 204(2); and Constitution Act, s 23.

72 District Court Act, s 29(1); and Senior Courts Act, s 134(2).

73 Privy Council Hearing on the Report of the Chief Justice of Gibraltar under Section 4 of the Judicial Committee Act 1833: Referral Under Section 4 of the Judicial Committee Act 1883 (UKPC 43, 2009) at [204][205] and [265]-[266]. See Philip Joseph Constitutional and Administrative Law in New Zealand (4th ed, Thomson Reuters, Wellington, 2014) at [21.3(5)].

74 ER Act 2000, s 204(1); and for the High Court, Constitution Act, s 23. See also Senior Courts Act, s 134(1). 
contrast, to remove a District Court judge, the Governor-General acts on the advice of the AttorneyGeneral. ${ }^{75}$ An Associate Judge of the High Court can be removed by the Governor-General, "if the Governor-General thinks fit". ${ }^{76}$

\section{B Transfer of Proceedings}

As a superior court within its own specialist jurisdiction, the Employment Court can hear cases removed to it from the Employment Relations Authority. ${ }^{77}$ The High Court can similarly hear cases transferred to it from the District Court. ${ }^{78}$

\section{Full Court Sittings}

The Employment Court can sit as a Full Court, like the senior courts. Although the High Court can sit with two or more judges, ${ }^{79}$ its powers are normally exercised by a judge alone.

The Employment Court sits as a Full Court when there is an important or novel case to be decided, or when the approach in an earlier Court decision is to be revisited. It is a mechanism to ensure certainty and consistency in judgments, and in effect it amounts to a higher court within the court, as a Full Court decision carries greater precedental weight than that of a judge alone.

The District Court lacks the power to sit as a Full Court.

\section{Search and Freezing Orders}

Since 2011, the Employment Court has had the same powers to make a freezing order ("Mareva" injunction) and a search order ("Anton Piller" order) as the High Court. ${ }^{80}$ Freezing orders involve the freezing of the other party's or a non-party's assets. Search orders require the respondent to permit a search enabling the gathering of relevant evidence and are relevant to actions involving breach of confidence. Both freezing and search orders are normally ordered ex parte without the respondent being notified in advance, and they involve the exercise of an invasive and coercive power. They are therefore viewed as a serious inroad into a respondent's or a non-party's rights; this explains why such orders are conferred on the higher level courts. The power to make such orders is inherently possessed

\footnotetext{
5 District Court Act, s 29(1).

76 Senior Courts Act, s 134(2).

77 ER Act 2000, s 178.

78 District Court Act, ss 86-89.

79 Senior Courts Act, ss 9 and 15.

80 ER Act 2000, s 190(3), as amended in 2010.
} 
only by the High Court. In order to be exercised by other courts, the power must be expressly conferred by statute, ${ }^{81}$ as is the case with the Employment Court.

In contrast, the District Court lacks the power to make a search order, ${ }^{82}$ and its power to make a freezing order is more circumscribed. First, the District Court's power is limited to "restraining a party to a proceeding ... from removing from New Zealand, or otherwise dealing with, assets in New Zealand", ${ }^{83}$ whereas the High Court's (and Employment Court's) power of restraint extends to assets located outside New Zealand. ${ }^{84}$ Moreover, in addition to restraining the respondent from "dealing with" the relevant assets, the High Court rules also cover "diminishing the value of" the assets. Finally, the District Court's power is limited to making a freezing order against "a party to a proceeding", ${ }^{85}$ whereas the High Court (and Employment Court) may also make a freezing order against a nonparty. 86

\section{E Monetary Awards}

The Employment Court, like the High Court, has no limit on the amount of damages it can award. The District Court is limited to a maximum of $\$ 350,000$.

\section{F Appeals}

\section{Appeal right to the specialist court}

Between 1908 and 1991, there was an appeal right from the District Court and its predecessors to the specialist court on labour-related matters.

Initially, penalties and orders imposed by the Court of Arbitration in respect of industrial awards and agreements could be enforced by a Magistrates' Court. ${ }^{87}$ Under the Industrial Conciliation and Arbitration Amendment Act 1908, such penalties could be sought in a Magistrates' Court by a party to the award or agreement, or by an Inspector of Awards, ${ }^{88}$ or in the Court of Arbitration by an

81 Axiom Rolle PRP Valuation Services Ltd v Kapadia [2006] 1 ERNZ 639 (EmpC), per the Full Court at [100].

82 District Court Act, s 21(3).

83 District Court Act, s 21(2).

84 High Court Rules 2016, r 32.2(2).

85 District Court Act, s 21(2).

86 High Court Rules, r 32.4.

87 IC\&A Amendment Act 1905, ss 30, 101 and 102.

88 Section 14(1) and (3). 
Inspector of Awards. ${ }^{89}$ In such actions, a Magistrate, before giving judgment, could state a case for the opinion of the Court of Arbitration. ${ }^{90}$

There was also an ordinary appeal right from a Magistrate's decision, but this was not to the Supreme Court or District Court, but to the Court of Arbitration "in the same manner as in the case of an appeal to the Supreme Court or District Court under the Magistrates' Courts Act, 1908", and the Court of Arbitration enjoyed "the same powers as the Supreme Court in respect of an appeal from the Magistrate's Court". ${ }^{91}$ The determination of the Court of Arbitration was final. An appeal right from the lower court to the specialist court, rather than the Supreme Court or (subsequently) the High Court, remained in place until 1991.

In 1937, the Court of Arbitration was empowered to delegate any of its powers to a Stipendiary Magistrate, with a right of appeal to the Court of Arbitration. ${ }^{92}$ This position was carried over into the IC\&A Act 1954, ${ }^{93}$ the IR Act $19733^{94}$ and the IR Amendment Act $1977 .{ }^{95}$ Under the LR Act 1987, the Labour Court could delegate its powers or functions to a District Court judge in respect of recovery of wages and penalty actions, with an appeal right to the Labour Court. ${ }^{96}$

\section{Appeal right from the specialist court}

Initially, in 1905, the appeal right from the Court of Arbitration was by way of case stated to the Supreme Court (now High Court) on a point of law. ${ }^{97}$ This was changed in 1908 to the Court of Appeal, ${ }^{98}$ and it has remained so, ${ }^{99}$ except that the appeal is no longer by way of case stated, but (since 1991) by direct appeal by a party to the proceedings on a question of law. ${ }^{100}$

89 Section 21(1).

90 Section 18

91 Section 19(1)-(2), subsequently amended by the Industrial Conciliation and Arbitration Amendment Act 1911, s 9.

92 Industrial Conciliation and Arbitration Amendment Act (No 2) 1937, s 4(1) and (3) respectively.

93 Section 37(1) and (6) respectively.

94 Section 48(1) and (6) respectively. The Court was re-established as the Industrial Court.

95 Section 49(1) and (6) respectively. The Court was re-established as the Arbitration Court.

96 Section 292(1) and (6) respectively.

97 IC\&A Amendment Act 1905, s 4; and IC\&A Amendment Act 1908, s 106.

98 IC\&A Amendment Act 1908, s 59(1).

99 IC\&A Act 1925, s 105; IC\&A Act 1954, s 38; IR Act 1973, s 51; IR Amendment Act 1977, s 62A(1); and LR Act 1987, s 312. Under the LR Act 1987, there was also an ordinary appeal right for decisions dealing with torts, contempt and applications for review: ss 309-311.

100 EC Act 1991, s 135; and ER Act 2000, s 214. 
The appeal right from the Employment Court to the Court of Appeal is analogous to the appeal right from the High Court to the Court of Appeal. In contrast, the appeal right from the District Court to the High Court is a general right of appeal and is not limited to questions of law. ${ }^{101}$

There are two restrictions on the scope of the Court of Appeal's (and now the Supreme Court's) ${ }^{102}$ appeal jurisdiction. One is that there can be no appeal "on the construction of an individual employment agreement or a collective employment agreement". ${ }^{103}$ The Court of Appeal and the Supreme Court, begrudging any inroad into their own jurisdiction by a court beneath them in the judicial hierarchy, have tended to find ways around this limitation when a different interpretation (or approach) is considered to be warranted.

Under the EC Act 1991, the courts of general jurisdiction lost their jurisdiction over individuals' employment contracts. The interpretation of the common law contract of service was now treated on the same footing as collective agreements, which had long been the exclusive domain of the specialist court. Perhaps it was inevitable that the extension of the specialist court's jurisdiction over "individual employment contracts" would colour the appeal courts' approach to dealing with their freshly lost jurisdiction, so that they tended to take a narrow view as to what fell within and what fell outside their jurisdiction. Moreover, the appeal courts' approach to dealing with the interpretation of individual contracts in turn crossed over to affect their approach to collective contracts as well. The Court of Appeal's previous "deferential approach" to the specialist court's decisions ${ }^{104}$ was arguably affected by this combined effect.

In the early 1990s, the Court of Appeal therefore began to draw a distinction between the specialist court's construction of employment contracts, which they would respect, and wider issues of legal principle, which they would not. This distinction was not always coherent. Thus, in Waitemata District Health Board v New Zealand Public Service Association, ${ }^{105}$ Chambers J of the Court of Appeal remarked that there were: ${ }^{106}$

... numerous decisions of this court, not all reconcilable. What amounts to "construction" has been the

subject of such subtle interpretation that no employment lawyer could be confident in advising a client

101 District Court Act, s 124

102 ER Act 2000, s 214A.

103 ER Act 2000, s 214(1). Compare EC Act 1991, s 135(1) (which referred to "individual employment contracts" and "collective employment contracts"; LR Act 1987, s 312(a) (which referred to "any award or agreement"); IR Amendment Act 1977, s 62A(1); and IR Act 1973, s 51 (both of which referred to "any award or collective agreement").

104 See Secretary for Education v Yates [2004] 2 ERNZ 313 (CA) at 319 per McGrath J.

105 Waitemata District Health Board v New Zealand Public Service Association [2006] 1 ERNZ 1029 (CA).

106 At [30]. 
dissatisfied with an Employment Court decision involving the interpretation of an employment agreement whether an appeal to this Court was barred by the construction privative provision.

Chambers $\mathrm{J}$ considered that a review by the appeal court of the law in this area was needed, and observed: ${ }^{107}$

It was during the 1990s that this court developed distinctions between pure interpretation (which is not amenable to review) and other errors such as "approach to interpretation" which can apparently be reviewed. I would have to say that, in some of those cases, I think this Court may have exceeded its jurisdiction. It could not resist the temptation to correct legal error when it perceived it. I confess to that temptation myself in the present case. Having seen what was in my view error in the Employment Court's approach, I did look to see whether I could categorise that error as an error other than one of construction. In the end, I could not, but I confess I tried.

The other restriction on the Court of Appeal's jurisdiction is that it must have regard to the special jurisdiction and powers of the Employment Court. ${ }^{108}$ These include the court's equity and good conscience jurisdiction, the validation of informal proceedings, and joinder, waiver and extensions of time "according to the substantial merits and equities of the case". ${ }^{109}$ The Court's equity and good conscience jurisdiction ultimately stems from the IC\&A Act $1894 .{ }^{110}$

Anderson considers that after the enactment of the ER Act 2000, the Court of Appeal has retreated from its earlier approach of re-establishing "the traditional values of the common law" in the area of employment law, and again allowed the Employment Court to resume "a central role in developing the law in its specialist area". ${ }^{111}$ He concludes that: ${ }^{112}$

107 At [44]. In the Supreme Court decision in New Zealand Air Line Pilots' Association Inc v Air New Zealand Ltd [2017] NZSC 111, [2017] 1 NZLR 948 Glazebrook J, dissenting, commented at [214] that the majority's approach to taking jurisdiction over contractual interpretation "would lead to appellate courts effectively substituting their view for that of the Employment Court, contrary to the prohibition in s 214(1)".

108 ER Act 2000, s 216. See also EC Act 1991, s 137; LR Act 1987, s 314; and IR Act 1973 (as amended in 1977), s 62A(4).

109 ER Act 2000, ss 189, 219 and 221 respectively.

110 Section 61. See subsequently IC\&A Amendment Act 1905, s 80; IC\&A Amendment Act 1908, s 81; IC\&A Act 1925, s 80; IC\&A Act 1954, s 36; IR Act 1973, s 47(4); IR Amendment Act 1977, s 47(4); LR Act 1987, s 279(4); and EC Act 1991, s 104(3).

111 Anderson "The Common Law and the Reconstruction of Employment Relationships in New Zealand", above n 43, at 114 .

112 At 115. 
Since the early part of this century, partly reinforced by the Supreme Court's stressing of the limitations on appeal, the Court of Appeal has again given considerable deference to the expertise of the Employment Court.

While there are a few appellate decisions that support Anderson's view, ${ }^{113}$ there are others that do not, including the Court of Appeal and Supreme Court decisions in Air New Zealand Ltd v New Zealand Air Line Pilots' Association Inc. ${ }^{114}$

Appeals against review decisions of the Employment Court are similarly made to the Court of Appeal, ${ }^{115}$ rather than the High Court, and the Court of Appeal must have regard to the "special jurisdiction and powers of the court" and related matters, ${ }^{116}$ as with the appeal right discussed above. Appeals relating to the specialist court's tort ${ }^{117}$ and contempt ${ }^{118}$ jurisdictions are also made to the Court of Appeal.

\section{G Review of the Specialist Court}

Legislatures may limit judicial review of some administrative and specialist tribunals and courts through privative or ouster clauses that purport to exclude review by higher courts. In relation to labour statutes, this is usually on the basis that the labour tribunal or court has specialist expertise: ${ }^{119}$ that it routinely deals with issues of mixed law and fact in its specialist area and that the judges of the specialist court possess judicial qualifications.

On the basis of a succession of privative clauses in New Zealand, the specialist court has not been subject to judicial review except for lack of jurisdiction since $1894 .{ }^{120}$ After the Anisminic Ltd $v$

113 See particularly Bryson v Three Foot Six Ltd [2005] NZSC 34, [2005] 3 NZLR 721.

114 Air New Zealand Ltd v New Zealand Air Line Pilots' Association Inc [2016] NZCA 131, [2016] 2 NZLR 829; and New Zealand Air Line Pilots' Association Inc v Air New Zealand Ltd, above n 107. See Alan Toy "Coup de Grâce for the Employment Court's Exclusive Power of Construction of Employment Agreements?" [2018] NZ L Rev 219.

115 ER Act 2000, s 218. See also EC Act 1991, s 133; and LR Act 1987, s 310.

116 ER Act 2000, s 216; EC Act 1991, s 137; and LR Act 1987, s 314.

117 ER Act 2000, s 214 (subsumed now under appeals on questions of law). In prior legislation this appeal right was contained in a stand-alone provision: EC Act 1991, s 132; and LR Act 1987, s 309.

118 ER Act 2000, s 217. See also EC Act 1991, s 133; and LR Act 1987, s 310.

119 See for example the leading Canadian review case on judicial deference in Canadian Union of Public Employees v New Brunswick Liquor Corporation [1979] 2 SCR 227, which concerned a complaint against the Public Service Labour Relations Board.

120 IC\&A Act 1894, s 72; IC\&A Amendment Act 1905, s 96; IC\&A Amendment Act 1908, s 96(2); IC\&A Act 1925, s 97; IC\&A Act 1954, s 47(1); and IR Act 1973, s 47(6). 
Foreign Compensation Commission case, ${ }^{121}$ where the House of Lords specified what sorts of errors could be considered as jurisdictional, labour legislation beginning with the IR Amendment Act 1977 expressly specified the circumstances where the specialist court lacks jurisdiction to make the relevant decision, order, or inquiry. ${ }^{122}$ These are where: ${ }^{123}$

(a) in the narrow and original sense of the term jurisdiction, it has no entitlement to enter upon the inquiry in question; or

(b) the decision or order is outside the classes of decisions or orders which the court is authorised to make; or

(c) the court acts in bad faith.

The Employment Court's traditional protection from review, subject to narrow exceptions, is consistent with its status as a specialist stand-alone court. In any case, the existence of a right to seek review of the specialist court's decisions is less important given the right to appeal to the Court of Appeal on questions of law, which should allow sufficient judicial supervision over the court. That check, through both appeal and review, however, rests with the Court of Appeal, not the High Court (which lost its jurisdiction over review of the specialist court in 1987). ${ }^{124}$

\section{Is the Employment Court an "inferior court"?}

The question whether the Employment Court is an "inferior court" is largely a moot one. The now repealed Judicature Act 1908 defined an "inferior court" as "any Court of judicature within New Zealand of inferior jurisdiction to the High Court". The Employment Court, however, is not an "inferior court" in terms of the definition in the Inferior Courts Procedure Act 1909, where "inferior court" is defined as

(a) the District Court:

(b) the Disputes Tribunal constituted under the Disputes Tribunal Act 1988:

(c) a District Court Judge, Justice of the Peace, Community Magistrate, Coroner, or Referee of the Disputes Tribunal in respect of the exercise on any judicial authority conferred upon him or her by an Act.

121 Anisminic Ltd v Foreign Compensation Commission [1969] 2 AC 147 (HL).

122 Section 48(6), re-enacted in the LR Act 1987, s 279(6)-(7); EC Act 1991, s 104(5)-(6); and ER Act 2000, s 193(1)-(2).

123 ER Act 2000, s 193(2). Except for the ground of bad faith in para (c), these grounds exclude the more numerous Anisminic grounds of review, above n 121.

124 LR Act 1987, s 308(2). 
The District Court has four divisions: a general division (for the exercise of its ordinary civil and criminal jurisdiction), the Family Court, the Youth Court and the Disputes Tribunal. ${ }^{125}$

Judges in the Environment Court must either be a District Court judge at the time of appointment, or be appointed as a District Court judge at that time. ${ }^{126}$ A Maori Land Court judge may be appointed as an alternate Environment judge. ${ }^{127}$ By virtue of the office, a Maori Land Court judge is a Justice of the Peace. ${ }^{128}$ Judges of the Maori Land Court are judges of the Maori Appellate Court. ${ }^{129}$ The Taxation Appeal Authority consists of a District Court judge or a barrister and solicitor of at least seven years' practice. ${ }^{130}$ The Victims' Special Claims Tribunal also consists of a District Court judge. ${ }^{131}$

Although the term "inferior court" has been a term of art in New Zealand law, it has never been statutorily applied to the Employment Court (or its predecessors), which is a stand-alone court under its own statutory regime and enjoys its own exclusive jurisdiction. The Arbitration Court once described itself and the High Court as each "a superior court within its own jurisdiction". 132

Case law, however, has viewed the Employment Court as an inferior court. In a 1983 case, ${ }^{133}$ the Court of Appeal considered the Arbitration Court to be of inferior jurisdiction to the High Court, though the basis for this (the High Court's review jurisdiction over the Arbitration Court) no longer applied after enactment of the LR Act 1987, and the lack of inherent powers to punish for disobedience to its orders has since been addressed by provisions for compliance orders and penalties.

In Attorney-General v Reid, ${ }^{134}$ the High Court, sitting as a Full Court, held that the Employment Tribunal and Court were "inferior courts" for the purposes of the High Court declaring a litigant to be vexatious under s 88A of the Judicature Act 1908. The High Court did accept, however, that in so far

125 District Court Act, s 9.

126 Resource Management Act 1991, s 249(1).

127 Resource Management Act, s 249(2).

128 Te Ture Whenua Maori Act 1993, s 7(5).

129 Te Ture Whenua Maori Act, s 51(1).

130 Taxation Authorities Act 1994, s 5.

131 Prisoners' and Victims' Claims Act 2005, s 58.

132 Wellington, Taranaki and Marlborough Clerical IUOW v Greenwich (t/a Greenwich and Associates) Employment Agency and Complete Fitness Centre [1983] ACJ 965 (Arbitration Court) at 980.

133 Quality Pizzas Ltd v Canterbury Hotel Employees Industrial Union [1983] NZLR 612 (CA).

134 Attorney-General v Reid [2000] 2 NZLR 377 (HC) decided under the EC Act 1991. 
as "the Employment Court has 'exclusive' or 'full and exclusive' jurisdiction in certain areas it cannot be of inferior jurisdiction to this Court in those areas". ${ }^{135}$

The law on vexatious litigants as applied in Attorney-General $v$ Reid, however, has since changed. Employment Court and District Court judges now have the power to make orders restricting a person from commencing or continuing civil proceedings in their respective courts with limited or extended effect. ${ }^{136}$ A judge of the High Court may make the same types of orders, in addition to an order that has general effect extending to another court or a tribunal. ${ }^{137}$ The wider jurisdiction of the High Court is logical in this context, since the jurisdiction of the Employment Court is restricted to the employment law sphere, and the jurisdiction of the District Court is more limited than that of the High Court. There is no reason why the Employment Court should have the power to prevent access to courts or tribunals other than those within its specialist jurisdiction.

In another case, the High Court, relying on Attorney-General $v$ Reid, ordered a stay of proceedings in the Employment Court where there were associated issues to be determined in each of the two courts. ${ }^{138}$ The decision, however, cautioned that the High Court judge hearing the case should not adjudicate upon any matters that fell within the Employment Court's exclusive jurisdiction. ${ }^{139}$

Because the specialist court is a creation of statute, it lacks the inherent jurisdiction of the High Court to punish for contempt, and in this respect its position is analogous to that of the District Court. ${ }^{140}$ This was recognised in the Law Commission's work on the law of contempt, ${ }^{141}$ which in turn has been carried over into the Administration of Justice (Reform of Contempt of Court) Bill 2018. ${ }^{142}$ The Bill proposes to amend the contempt provision (s 196) of the ER Act 2000 so that the Bill would apply to the Employment Court as if it were the District Court, and an Employment Court

135 At [23].

136 ER Act 2000, s 222C; and District Court Act, s 213.

137 Senior Courts Act, s 166

138 van den Brink v Smith [2001] 1 NZLR 103 (HC).

139 At [23].

140 As a court of record the Employment Court, like the District Court, has an implied or inherent jurisdiction to make such orders as are necessary to enable it to function effectively: New Zealand Railways Corporation $v$ New Zealand Seamen's IUOW [1989] 2 NZILR 613 (Labour Court), at 623; and United Food \& Chemical Workers Union of New Zealand v Talley [1992] 1 ERNZ 756 (Labour Court) at 776-777. This power is implicitly recognised in s 196(2) of the ER Act 2000 ("Contempt of court or Authority"), which provides that "[n]othing in this section limits or affects any power or authority of the court to punish any person for contempt of court in any case to which this section does not apply."

141 Law Commission Contempt in Modern New Zealand (NZLC IP36, 2014) at [Appendix B].

142 Administration of Justice (Reform of Contempt of Court) Bill 2018 (39-1). 
judge were a District Court judge. ${ }^{143}$ At the Bill's first reading, the Minister of Justice, the Hon Andrew Little, observed that the Arbitration Court right down to the advent of the Labour Court "was staffed by judges from what was then the Supreme Court", ${ }^{144}$ which is not precisely true. However, the point seems irrelevant to the law of contempt, which applies to the court concerned, and not the particular judge, whatever his or her judicial provenance. Opposition member and former AttorneyGeneral, the Hon Christopher Finlayson, agreed with the need to restore the specialist court to its proper historical status. He acknowledged that the Employment Court "is not part of the District Court system", but "the equivalent for industrial relations matters of the High Court". ${ }^{145}$

One may conclude, therefore, that the Employment Court is somewhat of a hybrid: it is equal to the High Court in matters that fall within its specialist jurisdiction, but inferior in relation to matters that are outside its statute or jurisdiction.

\section{CONSTITUTIONAL CONSIDERATIONS}

A court's status in the judiciary is constitutionally important for the credibility and effectiveness of its supervisory jurisdiction. This is particularly necessary for its role in providing institutional protection for the legal decision-making bodies beneath it. ${ }^{146}$ In $S v$ Van Rooyen, the Constitutional Court of South Africa observed: ${ }^{147}$

Lower courts are ... entitled to protection by the higher courts should any threat be made to their independence. The greater the protection given to the higher courts, the greater is the protection that all courts have.

In regard to the Employment Court, its position in the judicial hierarchy is important for preserving the independence and impartiality of the Employment Relations Authority, officers of the Authority and Court, as well as for serving as a check on relevant decision-making powers of the executive branch of government. To those ends, it has a review jurisdiction over the Authority, as well as over relevant powers of the Minister of Workplace Relations and Safety, the Registrar of Unions, the Minister of State Services, the State Services Commissioner and chief executives. ${ }^{148}$

143 Administration of Justice Bill, above n 142, sch 2 ("Consequential amendments to other enactments").

144 (2 May 2018) 729 NZPD (Administration of Justice (Reform of Contempt of Court) Bill - First Reading, Andrew Little).

145 (2 May 2018) 729 NZPD (Administration of Justice (Reform of Contempt of Court) Bill - First Reading, Christopher Finlayson).

146 See generally S v Van Rooyen [2002] ZACC 8, 2002 (5) SA 246 at [23] and [87]; and discussion in Andrew Butler and Petra Butler The New Zealand Bill of Rights Act: A Commentary (2nd ed, LexisNexis, Wellington, 2015) at [23.13.15]-[23.13.16].

147 Van Rooyen, above n 146, at [23].

148 ER Act 2000, s 194(1). 
The status of the Employment Court as a higher court roughly on par with the High Court needs to be maintained so that it may deal with the executive branch of government, when necessary, on appropriate terms and withstand any political pressure that might be brought to bear. In particular, given that the personnel and operation of the Employment Relations Authority may be affected by decisions of the executive branch, a credible supervisory jurisdiction is necessary as a check against threats to its independence. ${ }^{149}$ Although the Authority is not a "court", it is a quasi-judicial institution. Authority proceedings are "judicial proceedings" in so far as the immunities and privileges of Authority members, representatives, parties and witnesses are concerned, ${ }^{150}$ and Authority members enjoy the same protection as Justices of the Peace acting in their criminal jurisdiction. The oath of office of Authority members provides that they will "faithfully and impartially perform their duties". ${ }^{151}$ The perception of independence is as important as independence in fact. ${ }^{152}$ The Employment Court is the guarantor of that independence.

Section 194 of the ER Act 2000 sets out the review jurisdiction of the Employment Court and refers to the supervisory jurisdiction over a number of different decision-makers in the executive branch of government. Although a rarely, if ever, invoked jurisdiction, the potential for judicial review nevertheless stands as a counterpoise to possible abuses of power by the executive.

The decision-making powers of the Minister of Workplace Relations and Safety under the ER Act 2000 include:

- Recommending to the Governor-General persons to be appointed as members of the Authority. ${ }^{153}$ Removal from office is effected by the Governor-General, presumably on the Minister's advice. ${ }^{154}$

- $\quad$ Powers in respect of various codes under the ER Act 2000:

o Appointing committees for recommending codes of good faith, and then approving or declining approval for the codes. The Minister may amend or revoke codes in the same manner. ${ }^{155}$

149 See also Van Rooyen, above n 146, at [25]

150 ER Act 2000, s 176(2).

151 ER Act 2000, s 168.

152 Butler and Butler, above n 146, at [23.13.17] and the references to South African, Canadian, and European Court of Human Rights jurisprudence therein.

153 Sections 167 and 172 (temporary appointments).

154 Section $170(1)$.

155 Sections 35-38. See also ss 100D and 100F respectively in relation to codes of good faith for the public health sector and the New Zealand Police. 
o Approving, amending or revoking codes of employment practice. ${ }^{156}$

o Recommending that the Governor-General amend or replace the code of good faith for the public health sector in sch $1 \mathrm{~B},{ }^{157}$ and the code of good faith for employment relationships in respect of the New Zealand Police in sch 1C. 158

- Approving courses of employment relations education. ${ }^{159}$

The decision-making powers of the chief executive of MBIE include:

- Appointing the Registrar and Deputy Registrar of Unions; ${ }^{160}$ Authority officers to act under the general direction of the chief executive; ${ }^{161}$ Employment Court Registrars and other officers of the Court; ${ }^{162}$ and Labour Inspectors. ${ }^{163}$

- Employing or engaging mediators and ensuring their independence. ${ }^{164}$

- Providing mediation services generally and ensuring the provision of mediation when receiving a strike or lockout notice. ${ }^{165}$

- Issuing and revoking a certificate of exemption on religious grounds to an employer who is an individual. ${ }^{166}$

The decision-making powers of the Registrar of Unions are to decide whether or not to register a society as a union, and to decide if the preconditions for cancelling the registration of a union have been satisfied. ${ }^{167}$

156 Sections 100A-100C and 69ZA (which deal with a code of employment practice on the provision of breastfeeding facilities and breaks).

157 Section 100E.

158 Section $100 \mathrm{G}$.

159 Section 72.

160 Section 27.

161 Section 85.

162 Section 198.

163 Section 223.

164 Sections 144 and 153 respectively.

165 Sections 145 and 92 respectively.

166 Section 24.

167 Sections 15 and 17 respectively. 
Parts 5, 6, 7 and 7A of the State Sector Act confer decision-making powers upon the Minister of State Services, ${ }^{168}$ the State Services Commissioner, and chief executives of government departments. These powers include:

- $\quad$ The drafting by the State Services Commissioner of a government workforce policy and submission of it to the Minister for State Services for approval as a Government Workforce Policy Statement. ${ }^{169}$ A Government Workforce Policy Statement can be amended, revoked, or replaced in the same manner as it is made. ${ }^{170}$

- The operation by chief executives of government departments of personnel policies that comply with the principle of being a good employer. ${ }^{171}$ In making appointments, they must give preference to the person who best suits the position. ${ }^{172}$ Chief executives must also put in place a procedure for reviewing appointments that are the subject of employee complaint, and such procedures must be approved by the State Services Commissioner. ${ }^{173}$ The chief executive of the Ministry of Education may prescribe matters that employers must take into account when assessing the performance of teachers. ${ }^{174}$

- The State Services Commissioner can set minimum standards of integrity and conduct, issue a code of conduct, and apply it. ${ }^{175}$ Some agencies may derogate from a particular standard if the agency has obtained prior approval from its responsible Minister. ${ }^{176}$ A code of conduct for the education service, or different parts of the education service, may be issued from time to time by the chief executive of the Ministry of Education. ${ }^{177}$

- $\quad$ The State Services Commissioner acts as the employer for negotiating collective agreements in the public service, and must conduct the negotiations in consultation with the chief executive of the relevant department. ${ }^{178}$ The Commissioner acts in a similar capacity in

168 Their decisions would be potentially reviewable as those of "any other person" in s 194(1)(h) of the ER Act 2000. "Minister" in s 194(1)(f) refers to the Minister of MBIE, as defined in s 5, who is responsible for the administration of the ER Act 2000.

169 State Sector Act 1988, s 55B.

170 ER Act 2000, s 55C(2).

171 Section 56. The same obligation rests on every employer in the education service: s 77A.

172 Section 60.

173 Section 65.

174 Section 77C.

175 Section 57.

176 Section 57A.

177 Section 77B.

178 Section 68. 
respect of the education service, in consultation with the chief executive of the Ministry of Education and relevant employer representatives. ${ }^{179}$ In collective bargaining for the education service, the Commissioner has the power to lock out or suspend striking employees. ${ }^{180}$

- Employers in the education service make decisions on individual employees and must make appointments on the basis of merit. ${ }^{181}$

The enumeration of the various possible statutory powers of decision above may nearly rival Homer's "book of ships" for dryness, ${ }^{182}$ but it is important to appreciate the current extent of the Employment Court's review jurisdiction and the potential constitutional checks it represents.

\section{CONCLUSION}

It would be a vain task to attempt to place the Employment Court in the judicial hierarchy in terms of breadth of jurisdiction, as it is a specialist court, and to do so would in any event be comparing apples with oranges. Nevertheless, the indicators discussed above, in combination, point to the Employment Court's status as being roughly analogous with that of the High Court, if in some respects inferior to it. Relevant indicators include in particular:

- Exclusive jurisdiction over a number of causes of action: the industrial torts, injunctions in relation to industrial action, judicial review and employment contract matters, all carved out from the courts of general jurisdiction in 1987 and 1991.

- Operation as a second-tier legal institution, hearing appeals and matters removed from the legal forum below it.

- $\quad$ Ability to sit as a Full Court.

- Appeals from it (on points of law) and applications for review of the Employment Court are heard by the Court of Appeal rather than the High Court.

- Identical monetary jurisdiction as the High Court.

- Removal from the bench treated on the same footing as for High Court judges.

- The same powers as the High Court to make search and freezing orders, both of which involve the exercise of coercive powers not enjoyed by inferior courts.

The specialist court has acquired most of these features only over the past 30 years. At the same time, it has lost much of its original character due to increased judicialisation, and it is no longer

\footnotetext{
179 Section 74.

180 Section 74AA.

181 Sections 77F and 77G respectively.

182 The Iliad book II, which contains a list of Greek ships and associated contingents that sailed against Troy in the Trojan War and is a prime example of ancient catalogue poetry.
} 
engaged in its original function of wage-fixing. ${ }^{183}$ The specialist court is no longer playing its own game, which had entailed an equitable and common sense approach to deciding industrial matters. Even its ostensibly exclusive power to interpret individual and collective agreements has become open to examination by the appellate courts, despite the legislative prohibition to the contrary.

The Court of Appeal's 1984 comments on the nature of the specialist court seem far removed from the current position: ${ }^{184}$

It is not to be assumed that propositions of law, however prestigious and well established in the High

Court or the Court of Appeal, will apply with the same clear force in the Arbitration Court. That is a specialist Court, designed for a specific field. In the matters directed by the statute to come before it, it has exclusive jurisdiction, and, when exercising it, it must take into account other considerations besides legal issues. It is concerned primarily with fairness. Thus it has been more than once said in this Court that legal technicalities or analogy of rules will not always be helpful in achieving the objects of a Court which has been given what Cooke J has characterised as "unusual powers".

The decisions of the specialist court have now come to be measured against the approach of the courts of general jurisdiction, so that it is less a court of fairness and equity. The specialist court no longer enjoys the same status it once enjoyed under the conciliation and arbitration system. While in formal terms its position in the judicial hierarchy is somewhat below that of the High Court and above that of the District Court, one might question whether this should even be a relevant issue given the unique and specialist nature of its jurisdiction.

183 Thus, the s 5 definition of "employment relationship problem" in the ER Act 2000 "does not include any problem with the fixing of new terms and conditions of employment". In extreme cases where good faith has been seriously breached during collective bargaining so as to significantly undermine the bargaining, however, the low-level Employment Relations Authority may fix the terms of a collective agreement (s 50J): see First Union Inc v Jacks Hardware and Timber Ltd [2019] NZERA Christchurch 374, the first case in which this was done.

184 Winstone Clay Products Ltd v Inspector of Awards [1984] 2 NZLR 209 (CA) at 211. This was a case stated by the Arbitration Court in a dispute concerning the meaning of a collective agreement. See also New Zealand Van Lines Ltd v Gray [1999] 2 NZLR 397 (CA), which cited with approval Auckland Shop Employees Industrial Union v Imperial Supplies Ltd [1983] ACJ 729 (Court of Arbitration) at 740-741. 